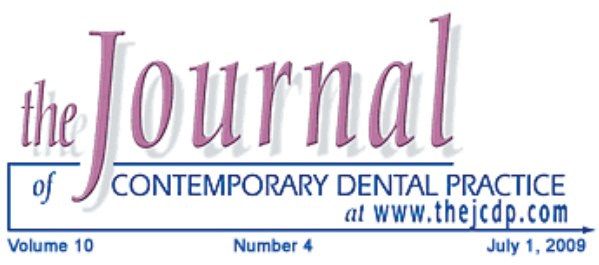

\title{
Stem Cells: Therapeutic Potential in Dentistry
}
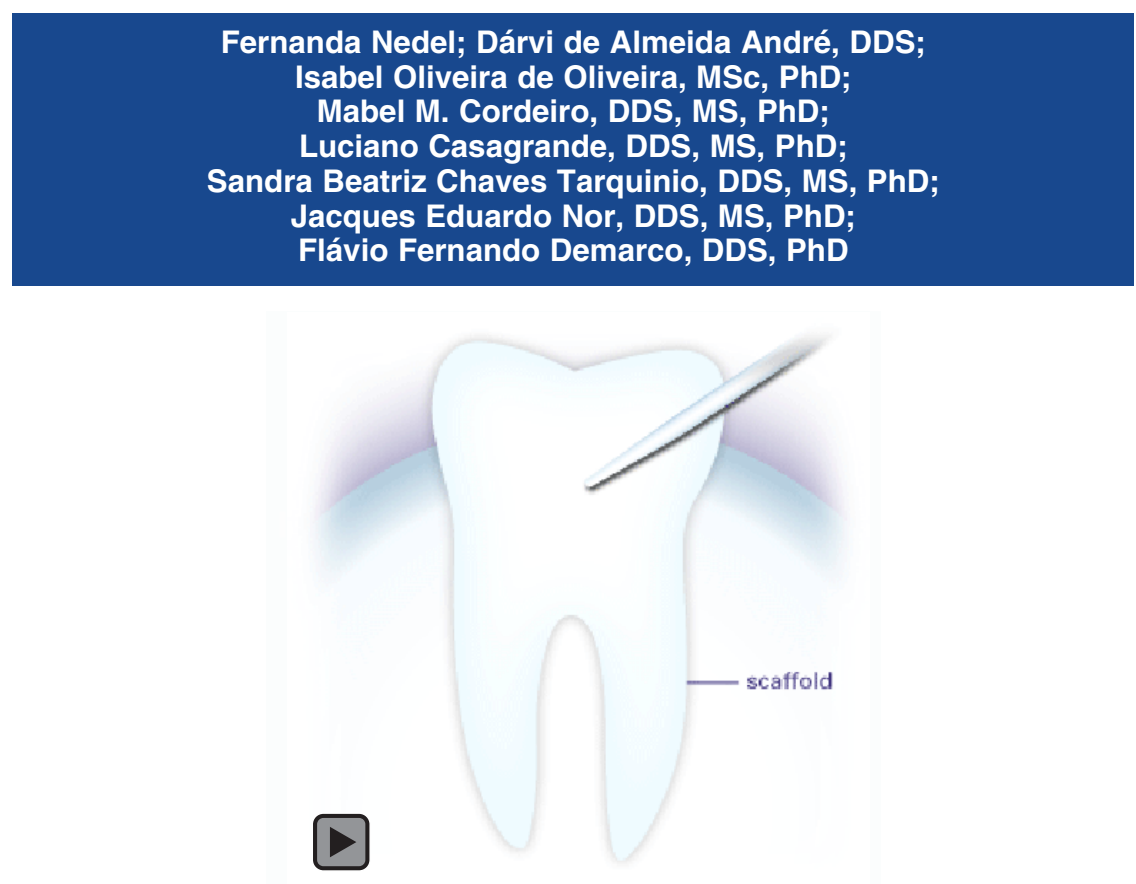

Abstract

Aim: The aim of this paper is to present a review and discussion of the current status of stem cell research with regard to tooth generation.

Background: Stem cells have been isolated from the pulp tissue of both deciduous and permanent teeth as well as from the periodontal ligament. Dental pulp stem cells demonstrate the capacity to form a dentin pulp-like complex in immunocompromised mice. A tooth-like structure was successfully formed, using a heterogeneous mixture of dental enamel epithelium, pulp mesenchymal cells, and scaffolds.

Conclusion: The scientific community understands the need for more investigations to completely understand the conditions that would best favor the creation of a tooth substitute. Recent gains in the understanding of the molecular regulation of tooth morphogenesis, stem cell biology, and biotechnology offers the opportunity to realize this goal.

Clinical Significance: These findings, combined with the recent progress in stem cell research and tissue engineering, might allow the development of alternatives for current materials and therapies used to treat tooth tissue loss (e.g., enamel, dentin, pulp), reconstruct dentoalveolar and craniofacial bone defects, and eventually replace an entire tooth.

(c) Seer Publishing 
Keywords: Stem cells, tissue engineering, dental practice

Citation: Nedel F, André DA, Oliveira IO, Cordeiro MM, Casagrande L, Tarquinio SBC, Nor JE, Demarco FF. Stem Cells: Therapeutic Potential in Dentistry. J Contemp Dent Pract 2009 July; (10)4:090-096.

\section{Introduction}

In general, human dental tissues have a limited potential to regenerate. However, recent progress in stem cell research and in tissue engineering promises novel prospects for dental tissue regeneration in future dental practice (Figure 1). ${ }^{1,2}$ Stem cells are generally defined as clonogenic cells capable of both self-renewal and multilineage differentiation ${ }^{3}$ since they are thought to be undifferentiated cells with varying degrees of potency and plasticity. ${ }^{4}$

There are basically two types of stem cells as follows: $: 3,5,6,7$

- Embryonic stem cells, located within the inner cell mass of the blastocyst stage of development.

- Post-natal stem cells that have been isolated from various tissues including bone marrow, neural tissue, skin, dental pulp, and the periodontal ligament.

The use of embryonic stem cells generates many ethical concerns regarding the consumption of blastocystes. ${ }^{8}$ This makes post-natal stem cells a more feasible approach for translation into clinical dental practice. ${ }^{5}$

The majority of craniofacial structures derive from mesenchymal cells which in turn are originated from the neural crest. During development these cells migrate, differentiate, and participate in the morphogenesis of all craniofacial structures (bone, cartilage, musculature, ligaments, teeth, and periodontum) working synergistically with mesodermal cells. Mesenchymal cells undergo asymmetric division with one offspring cell

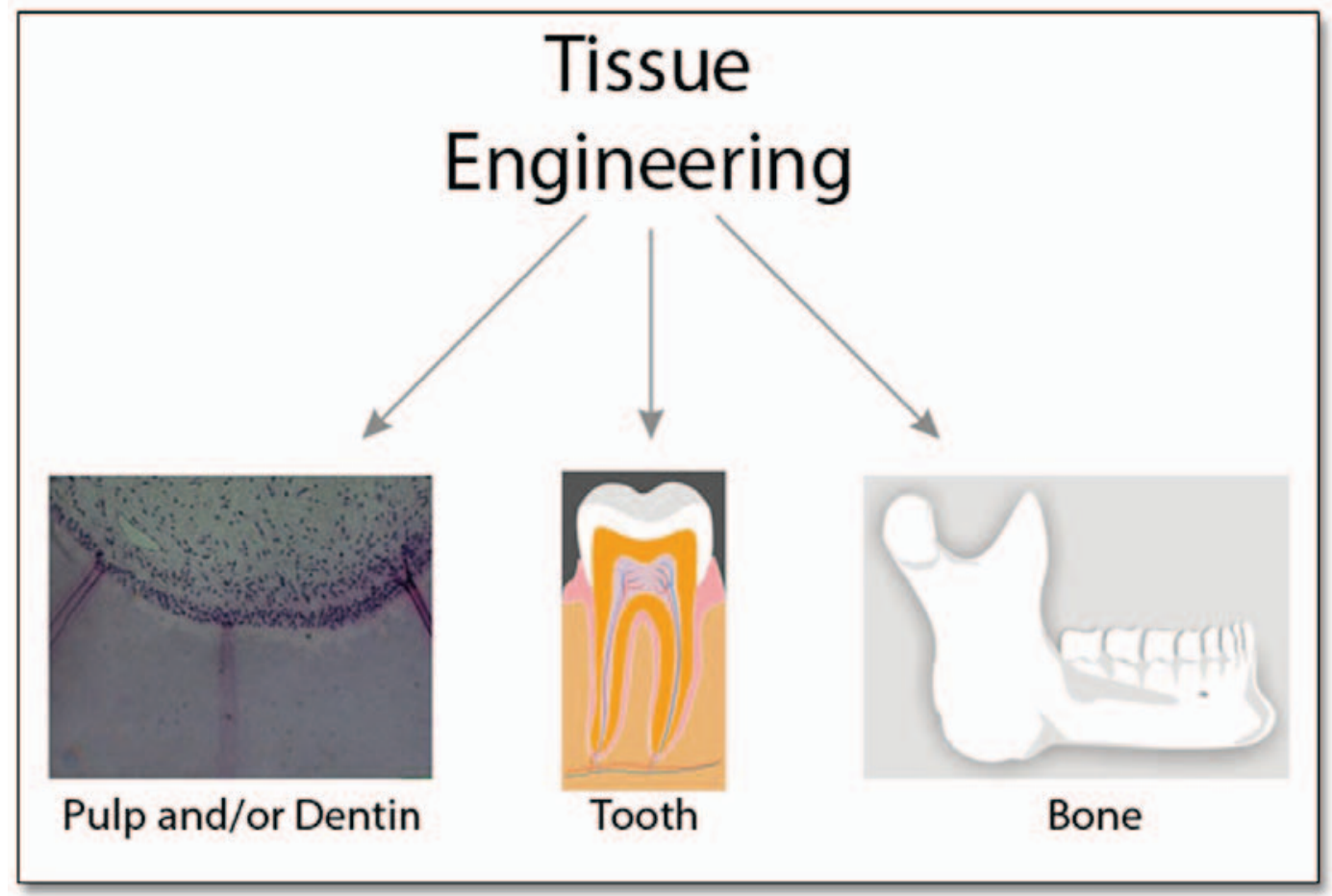

Figure 1. Potential future perspectives for tissue engineering in dentistry, forming different dental tissues or even a whole tooth. 


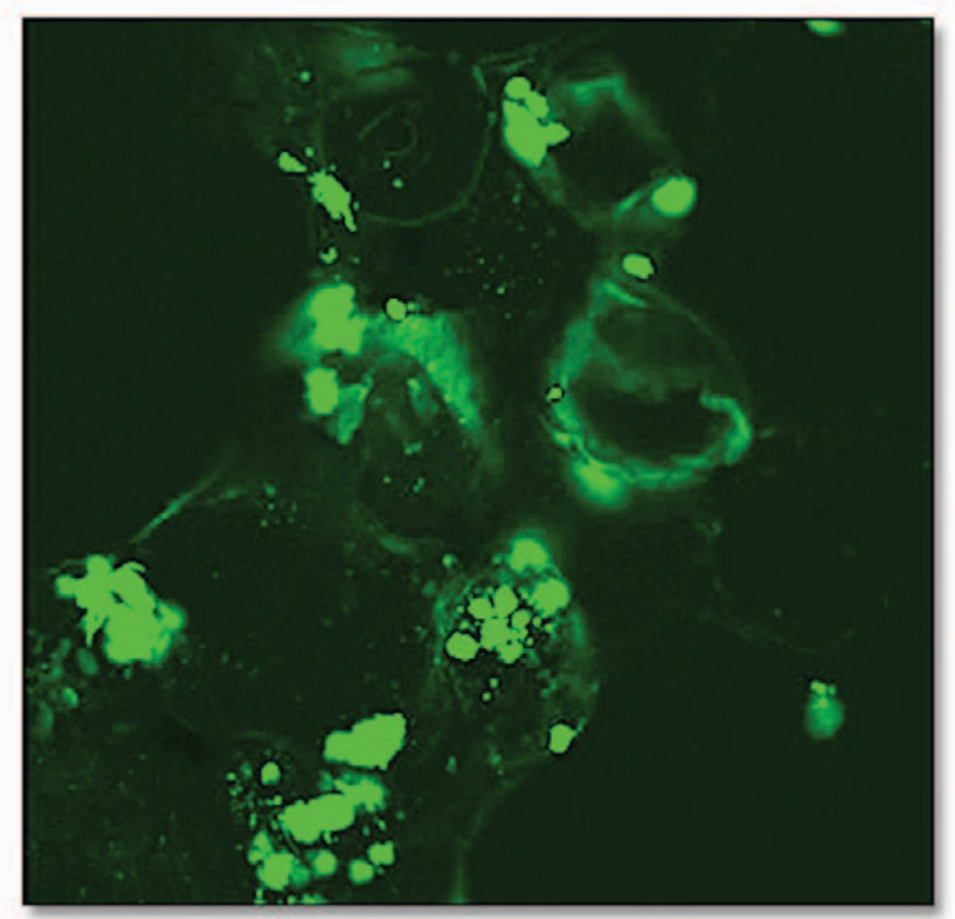

Figure 2. Visualization by confocal microscopy of DPSC seeded in a scaffold and marked with CFDA SR dye demonstrating the cell adhesion to the porosity of the scaffold.

differentiating toward an end-stage cell while the other one replicates into an offspring mesenchymal cell, keeping its stem cell status. ${ }^{3}$

Residual mesenchymal cells upon completion of morphogenesis continue to reside inside various tissues and are called mesenchymal stem cells. In the adult those cells maintain physiologically necessary tissue turnover and, after injury or disease, differentiate and launch tissue regeneration. ${ }^{9}$ It has been demonstrated stem cells are present within the pulp tissue of deciduous teeth (Stem Cells from Human Exfoliated Decíduous teeth - SHED), ${ }^{6}$ permanent teeth (Dental Pulp Stem Cells - DPSCs) (Figure $2),{ }^{10}$ and in the periodontal ligament (Periodontal Ligament Stem Cells - PDLSCs). ${ }^{7}$

To determine the existence of DPSCs, previously developed applied methodology was used for the isolation and characterization of bone marrow stromal cells (BMSCs) and pluripotent postnatal stem cells. DPSCs were characterized as a clonogenic and highly proliferative stem cell. ${ }^{10}$ Despite the different location in situ of DPSCs and (BMSCs) they share many similarities with respect to their expression of various proteins commonly present in the extracellular matrix of bone and dentin, being both able to form calcified deposits in vitro. ${ }^{10}$ Microarray analyses of gene expression profiles of DPSCs and BMSCs indicate these two distinct precursor populations have a similar level of gene expression. ${ }^{11}$

SHEDs when compared to DPSCs have a higher proliferation rate and are able to differentiate into a variety of cell types including neural cells and adipocytes, which might represent a more immature population of multipotent stem cells. ${ }^{6}$ PDLSCs also represent a population of multipotent cells and showed potential to form calcified deposits, however, they formed sparse calcifies nodules compared to DPSCs. ${ }^{4,7}$

Finally, expression of various perivascular markers provides clues. DPSCs, SHEDs, and PDLSCs are a population of mesenchymal stem cells and likely located in the perivacular niche within the pulp. ${ }^{7,12}$

Tissue engineering is an emerging and multidisciplinary field with the potential of 


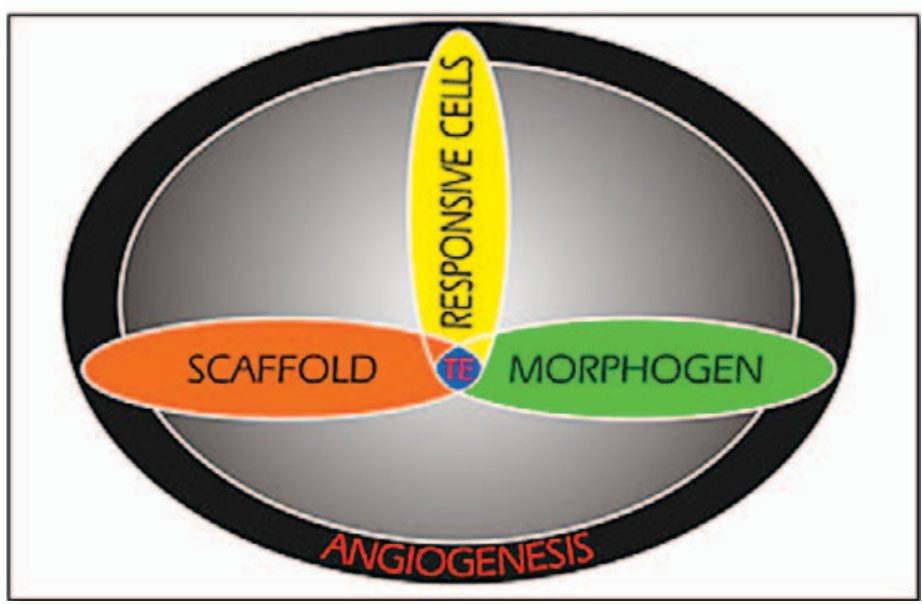

Figure 3. The three components of tissue engineering are: scaffolds, responsive cells, and morphogens which are essential for any tissue formation. Also, angiogeresis, required for most tissues, play significant roles in tissue engineering because without an adequate blood supply cells cannot survive leading to failure during the tissue engineering process.

designing and constructing tissues or organs in order to restore their function or even completely replace them. ${ }^{13-18}$ Tissue engineering is based on principles of molecular developmental biology governed by bioengineering. ${ }^{13-15,18}$ The three main components for morphogenesis and tissue engineering are: inductive signals, responding cells, and a scaffold (Figure 3$)^{14,15,19,20}$

Pulp-like tissue could be engineered in vitro, using DPSCs seeded into synthetic matrices made with polyglycolic acid. ${ }^{21,22}$ Biological scaffolds such as collagen and glycosaminoglycan could also be used and Bone Morphogenetic Proteins (BMPs) are considered major morphogenes for tooth regeneration. ${ }^{15,23}$

In a review on tissue engineering, Nakashima and Akamine ${ }^{15}$ emphasized that despite the significant progress in this area, numerous challenges still remain including neural and vascular regeneration. BMPs seem to have a pronounced effect on neurogenesis. ${ }^{24}$ As a result, BMPs used for regenerative pulp therapy could have concurrent beneficial effects on nerve regeneration. ${ }^{14,15}$ In addition, Vascular Endothelial Growth Factor (VEGF), which is used therapeutically to induce tissue neovascularization, is a potent inducer of endothelial cell survival and differentiation of new blood vessels. ${ }^{25,26}$ Currently, most approaches have successfully created a number of simple tissues but have not been successful in creating complex structures with specialized functions. ${ }^{5}$ The inability to develop a microvascular network to support the engineered structure could account for this lack of success. ${ }^{27}$ Vascularization is important to enable cell viability during tissue growth, induce structural organization, and promote integration upon implantation. ${ }^{28}$

\section{Reconstruction of Dental and Craniofacial Structures}

The new knowledge in tissue engineering and in molecular biology has amplified the possibilities of potential development of new biological therapies such as dental pulp capping and new methods to treat the dental root and periodontal diseases. ${ }^{23}$ In direct pulp capped teeth, a bridge of dentin is formed as a result of the recruitment and proliferation of undifferentiated pulp cells in response to the stimulus provoked by the calcium hydroxide. This strategy using calcium hydroxide has been used for many years in "dental tissue engineering". Once differentiated and organized the cells synthesize the extracellular matrix which, in turn, will undergo mineralization. Studies in mice have shown bioactive molecules present in the extracellular matrix induce the formation of a dentin bridge or a wide mineralized area in the coronal pulp. ${ }^{29}$ BMP is a protein which is included in the dental development, especially BMP-2 
type. They induce the formation of a significant amount of reparative dentin on the amputated pulp, suggesting BMPs can actually regulate the differentiation of pulp cells into odontoblasts and stimulate the formation of reparative dentin. ${ }^{19,23}$ In addition to BMP-2 other growth factors like TGF$\beta 1$, TGF- $\beta 3$, and IGF- 1 have been reported as being responsible for the signaling of progenitor cell differentiation into odontoblasts. ${ }^{6,29}$

Batouli et al. ${ }^{30}$ demonstrated the capacity of dental pulp stem cells to form a dentin pulp-like complex by transplanting them in immunocompromised mice. After 16 weeks, the pulp-like tissue contained a fibrous connective tissue, blood vessels, and odontoblasts associated with newly formed dentin indicating the possibility of using those stem cells for the repair of injured dental structures. It is still unknown which signals are required for the differentiation of cells that compose the dental pulp and how such signals should be spatially distributed in a timely manner represents a potential challenge to engineering a dental pulp. ${ }^{25}$

Therapies involving stem cells also hold promise for the treatment of periodontal disease. Recent studies revealed the presence of progenitor cells in the dental follicle, which can contribute to the formation of periodontal tissues (including cementum and the periodontal ligament) and odontoblasts. ${ }^{31}$ Kramer et al.$^{32}$ conducted an in vitro study to determine the potential of mesenchymal stem cells and progenitor cells from the periodontal ligament (PDL) tissue to produce different types of oral tissues as well as the possibility of repairing sequels caused by oral diseases. They demonstrated PDL-like tissue can be developed from periodontal progenitor cells and from mesenchymal stem cells in contact with either PDL factors or the tissue itself. This finding emphasizes the possibility of a clinical application of stem cells for repair and regeneration. Saito et al. ${ }^{31}$ suggested the use of BMP-2 as promoter for the differentiation of progenitor cells from the dental follicle into cementoblasts and odontoblasts in order to re-establish the integrity of the PDL. ${ }^{33}$ A recent study by Marei et al. ${ }^{34}$ demonstrated the implantation of an engineered porous scaffold seeded with bone marrow stem cells in a socket created by the extraction of the lower left central incisor in rabbits can preserve the alveolar bone walls, representing another step toward periodontal regeneration.

A limiting factor for the success of tissue engineering is the availability of rapid and effective vascularization to provide nutrients to the cells and maintenance of the newly created tissue. ${ }^{35}$ Cordeiro et al ${ }^{35,36}$ in a recent study investigated the possibility of engineering a vascularized functional pulp-like tissue. Biodegradable scaffolds were prepared inside the pulp cavity of tooth slices. SHED alone, or associated with Human Dermal Microvalcular Endolthelial cells (HDMEC), were seeded in the scaffold and subsequently implanted in immunodeficient mice. The engineered tissue presented cellularity, morphology, and gene expression resembling regular dental pulp with functional blood vessels. When SHED and HDMEC were co-implanted, the tissue obtained showed a higher level of organization although the presence of blood vessels were observed even in a SHED implantation only group. This can be explained by the capability of SHED cells to differentiate into endothelial cells. However, when both cell types were associated, the HDMEC cells could have rapidly formed blood vessels because they are end-stage cells. This could have guaranteed nutrients and cell survival from the initiation of tissue development. Cordeiro et al. ${ }^{35}$ demonstrated the feasibility of engineering a human dental pulp-like tissue using human SHEDs and primary human endothelial cells.

Progress in bone tissue engineering and cell culture techniques can also give rise to a new approach to reconstruction of bone defects or bone fractures. ${ }^{37}$ Studies involving bone regeneration in vitro are limited by the difficulty to obtain a cytotype capable of forming a complete tissue. DPSCs seem to be better candidates for the study of bone formation than bone marrow stem cells, due to their high proliferation rate and efficiency in producing bone chips. ${ }^{8}$ In a recent study, DPSCs gave rise to osteoblasts and endotheliocytes, and eventually to bone containing vessels capable of forming an adult bone tissue after transplantation in vivo. ${ }^{38}$ Currently mandibles with major discontinuities are repaired with autologous vascularized fibula or an iliac crest. However, this technique always creates another skeletal defect which is a major disadvantage.$^{39}$ Conejero et al. ${ }^{40}$ demonstrated bone defects in the palate of mice 
can be repaired with success using osteogenically differentiated fat-derived stem cells. Another study proved formation of heterotopic bone for a mandible replacement in a human is possible using a titanium scaffold (based on an ideal virtual replacement of the missing part of the mandible) filled with bone mineral blocks, recombinant human BMP7, and bone marrow. ${ }^{39}$ Alhadlaq et al. ${ }^{41}$ demonstrated the possibility of developing a chondrogenic and osteogenic layered humanshaped articular condyle using bone marrow mesenchymal stem cells encapsulated in a biocompatible poly(ethylene glycol)-based hydrogel and implanted subcutaneously in the dorsum of rats. Those studies showed post-natal stem cells could be useful in the reconstruction of bone defects in the craniofacial and dentoalveolar area.

\section{Formation of Complex Dental Structures}

Young et al. ${ }^{43}$ were successful in forming a complex dental structure for the first time using porcine third molars to obtain a heterogeneous mixture of dental enamel epithelium and pulp mesenchymal cells. ${ }^{9}$ Tooth-shaped scaffolds were created using biodegradable polymers into which the cellular mixtures were seeded then involved in omentum, a material rich in blood vessels to supply the developing tooth tissues with nutrients and oxygen. Subsequently, the surgical implantation of the complex was made in a host mouse. After 20 to 30 weeks, toothlike structures were visible within the confines of the original scaffolds. Their shape and tissue organization resembled the crowns of natural teeth. It was possible to recognize the presence of dentin, odontoblasts, a well-defined pulp chamber, putative Hertwig's root sheath epithelia, putative cementoblasts, and a morphologically correct enamel organ containing fully formed enamel. However, the bioengineered teeth were small and they did not adjust to the size and the form of the biodegradable scaffold. ${ }^{42}$

Ohazama et al. ${ }^{44}$ using mice proved the recombination of mesenchyme (created in vitro through the aggregation of cultured non-dental stem cells which express odontogenic genes and embryonic oral epithelium) stimulated an odontogenic response in the mesenchyme. When those embryonic tooth primordia were transferred into a renal capsule, they developed into coronal tooth shapes with associated bone and soft tissues. That discovery suggests dental tissues could be developed even in the absence of pure populations of stem cells. This finding could prove valuable in the future in the application of those procedures in humans. However, the clear formation of a tooth was only observed when the epithelium came from an embryonic source and the populations of mesenchyme cells possessed at least some stem cells. ${ }^{10,42}$

Until now, there has been no demonstration of development of a complete dental organ at its normal location in the adult body following transplantation of an embryonic primordium. However, Ohazama et al. ${ }^{44}$ have shown the transfer of an embryonic primordium into the jaw of an adult mouse results in the complete development of a tooth attached to the bone by a soft tissue in with a proper orientation and appropriate size for the mouse. ${ }^{44}$

\section{Conclusion}

The scientific community understands the need for more investigations to completely understand the conditions that would best favor the creation of a tooth substitute. Recent gains in understanding the molecular regulation of tooth morphogenesis, stem cell biology, and biotechnology offers the opportunity to realize this goal.

One of the next critical steps is to apply the knowledge of molecular regulation of tooth morphogenesis to manipulate adult stem cells. Scaffold characteristics such as porosity, degradation rate, and surface chemistry among other parameters have to be carefully considered and controlled for application to tooth regeneration. Angiogenesis is also crucial in the development of successful tissue engineering application for it supplies the cells with oxygen and nutrients. A need for the development and characterization of a means to induce angiogenesis remains. Another concern of researchers is convenient access to effective cellular material that is harvested from the patient in order to eliminate immunological rejections. Using harvested cells from the patient a tooth created through tissue engineering ${ }^{11}$ could potentially serve as a substitute for their natural tooth since the size, form, and color of the tooth are determined genetically. 
Despite the grandiosity of recent discoveries in the field of tissue engineering, more questions than answers exist. The enthusiasm accompanying scientific findings that raise the possibilities of a "custom tooth produced to order" using non-dental autologous cells or creating an in vitro primordium tooth for transplantation with the intention of replacing a lost tooth must be tempered since there are many more studies to be done to answer the questions that remain.

\section{Clinical Significance}

These findings, combined with the recent progress in stem cell research and tissue engineering, might allow the development of alternatives for current materials and therapies used to treat tooth tissue loss (e.g., enamel, dentin, pulp), reconstruct dentoalveolar and craniofacial bone defects, and eventually replace an entire tooth. 


\section{References}

1. Thesleff I. Developmental biology and building a tooth. Quintessence Int. 2003; 34(8):613-620.

2. Thesleff I, Tummers M. Stem cells and tissue engineering: prospects for regenerating tissues in dental practice. Med Princ Pract. 2003; 12(suppl. 1):43-50.

3. Gronthos S, Brahim J, Li W, Fisher LW, Cherman N, Boyde A, DenBesten P, Robey PG, Shi S. Stem Cell Properties of Human Dental Pulp Stem Cells. J Dent Res. 2002; 81(8):531-535.

4. Robey PG. Stem cells near the century mark. J Clin Invest. 2000; 105(11):1489-1491.

5. Krebsbach PH, Robey PG. Dental and Skeletal Stem Cells: Potential Cellular Therapeutics for Craniofacial Regeneration. J Dent Educ. 2002; 66(6):766-773.

6. Miura M, Gronthos S, Zhao M, Lu B, Fisher LW, Robey PG, Shi S. SHED: Stem cells from human exfoliated deciduous teeth. Proc Natl Acad Sci U S A. 2003 May 13;100(10):5807-5812.

7. Seo BM, Miura M, Gronthos S, Bartold PM, Batouli S, Brahim J, Young M, Robey PG, Wang CY, Shi S. Investigation of multipotent postnatal stem cells from human periodontal ligament. Lancet. 2004 Jul 10-16;364(9429):149-55.

8. Conrad C, Huss R. Adult Stem Cell Lines in Renegerative Medicine and Reconstructive Surgery. J Surg Res. 2005; 124(2):201-208.

9. Mao JJ, Giannobile WV, Helms JA, Hollister SJ, Krebsbach PH, Longaker MT, Shi S. Craniofacial Tissue Engineering by Stem Cells. J Dent Res. 2006; 85(11):966-979.

10. Gronthos S, Mankani M, Brahim J, Gehon Robey P, Shi S. Postnatal human dental pulp stem cells (DPSCs) in vitro and in vivo. PNAS. 2000; 97(25):13625-13630.

11. Shi S, Robey PG, Gronthos S. Comparison of human dental pulp and bone marrow stromal stem cells by cDNA microarray analysis. Bone. 2001; 29(6):532-9.

12. Shi S, Bartold PM, Miura M, Seo BM, Robey PG, Gronthos S. The efficacy of mesenchymal stem cells to regenerate and repair dental structures. Orthod Craniofac Res. 2005; 8(3):191-9.

13. Chai $Y$, Slavkin HC. Prospects for tooth regeneration in the 21st century: a perspective. Microsc Res Tech. 2003; 60(5):469-79.

14. Nakashima M. Bone morphogenetic proteins in dentin regeneration for potential use in endodontic therapy. Cytokine Growth Factor Rev. 2005; 16:369-376.

15. Nakashima M, Akamine A. The Application of Tissue Engineering to Regeneration of Pulp and Dentin in Endodontics. J Endod. 2005; 31(10):711-718.

16. Taba Jr. M, Jin Q, Sugai JV, Giannobile WV. Current concepts in periodontal bioengineering. Orthod Craniofacial Res. 2005; 8:292-302.

17. Srisuwan T, Tilkorn DJ, Wilson JL, Morrison WA, Messer HM, Thompson EW, Abberton KM. Molecular aspects of tissue engineering in the dental field. Periodontol 2000. 2006; 41:88-108.

18. Langer R, Vacanti JP. Tissue engineering. Science. 1993 May 14;260(5110):920-6.

19. Iohara K, Nakashima M, Ito M, Ishikawa M, Nakasima A, Akamine A. Dentin Regeneration by Dental Pulp Stem Cell Therapy with Recombinant Human Bone Morphogenetic Protein 2. Dent Res. 2004; 83(8):590-595.

20. Slavkin HC, Bartold PM. Challenges and potential in tissue engineering. Periodontology 2000. 2006; 41:9-15.

21. Buurma B, Gu K, Rutherford R. Transplantation of human pulpal and gingival fibroblasts attached to synthetic scaffolds. Eur J Oral Sci. 1999; 107:282-289.

22. Mooney DJ, Powell C, Piana J, Rutherford B. Engineering Dental Pulp-like Tissue in Vitro. Biotechnol Prog. 1996; 12:865-868.

23. Nakashima M, Tachibana K, lohara K, Ito M, Ishikawa M, Akamine A. Induction of reparative dentin formation by ultrasound-mediated gene delivery of growth/differentiation factor 11. Hum Gene Ther. 2003; 14:591-597.

24. Mabie PC, Mehler MF, Kessler JA. Multiple roles of bone morphogenetic protein signaling in the regulation of cortical cell number and phenotype. J Neurosci. 1999 Aug 15;19(16):7077-88.

25. Nör JE. Tooth regeneration in operative dentistry. Oper Dent. 2006 Nov-Dec;31(6):633-42. 
26. Nör JE, Christensen J, Mooney DJ, Polverini PJ. Vascular endothelial growth factor (VEGF)mediated angiogenesis is associated with enhanced endothelial cell survival and induction of Bcl-2 expression. Am J Pathol. 1999 Feb;154(2):375-84.

27. Tepper OM, Galiano RD, Kalka C, Gurtner GC. Endothelial progenitor cells: the promise of vascular stem cells for plastic surgery. Plast Reconstr Surg. 2003 Feb;111(2):846-54.

28. Levenberg S, Golub JS, Amit M, Itskovitz-Eldor J, Langer R. Endothelial cells derived from human embryonic stem cells. PNAS. 2002; 99(7):4391-4396.

29. Goldberg M. Cells and extracellular matrices of dentin and pulp: a biological basis for repair and tissue engineering. Crit Rev Oral Biol Med. 2004; 15(1):13-27.

30. Batouli S, Miura M, Brahim J, Tsutsui TW, Fisher LW, Gronthos S, Robey PG, Shi S. Comparison of Stem-cell-mediated Osteogenesis and Dentinogenesis. J Dent Res. 2003; 82(12):976-981.

31. Saito M, Handa K, Kiyono T, Hattori S, Yokoi T, Tsubakimoto T, Harada H, Noguchi T, Toyoda M, Sato S, Teranaka T. Immortalization of Cementoblast Progenitor Cells With Bmi-1 and TERT. J Bone Miner Res. 2005; 20(1):50.

32. Kramer PR, Nares S, Kramer SF, Grogan D, Kaiser M. Mesenchymal Stem Cells Acquire Characteristics of Cells in the Periodontal Ligament in vitro. Dent Res. 2004; 83(1):27-34.

33. Zhao M, Xiao G, Berry JE, Franceschi RT, Reddi A, Somerman MJ. Bone morphogenetic protein 2 induces dental follicle cells to differentiate toward a cementoblast/osteoblast phenotype. J Bone Miner Res. 2002; 17(8):1441-51.

34. Marei MK, Nouh SR, Saad MM, Ismail NS. Preservation and regeneration of alveolar one by tissueengineered implants. Tissue Eng. 2005 May-Jun 11(5-6):751-67.

35. Cordeiro MM, Dong Z, Kaneko T, Zhang Z, Miyazawa M, Shi S, Smith AJ, Nör JE. Dental pulp tissue engineering with stem cells from exfoliated deciduous teeth. J Endod. 2008 Aug;34(8):962-9.

36. Cordeiro MMR, Kaneko T, Zhang Z, Miyazawa M, Shi S, Smith AJ, Nör JE. Human Dental Pulp-Like Tissue Engineering Using Stem Cells and Endothelial Cells. In: 24 Reunião Anual da SBPQO, 2007, Atibaia. 2007.

37. Kimelman N, Pelled G, Gazit Z, Gazt D. Applications of gene therapy and adult stem cells in bone bioengineering. Regen Méd. 2006 July;1(4):549-561.

38. d'Aquino R, Graziano A, Sampaolesi M, Laino G, Pirozzi G, De Rosa A, Papaccio G. Human postnatal dental pulp cells co-differentiate into osteoblasts and endotheliocytes: a pivotal synergy leading to adult bone tissue formation. Cell Death Differ. 2007 Jun;14(6):1162-1171.

39. Warnke PH, Springer IN, Wiltfang J, Acil Y, Eufinger H, Wehmöller M, Russo PA, Bolte H, Sherry E, Behrens E, Terheyden H. Growth and transplantation of a custom vascularised bone graft in a man. Lancet. 2004 Aug 28-Sep 3;364(9436):766-70.

40. Conejero JA, Lee JA, Parrett BM, Terry M, Wear-Maggitti K, Grant RT, Breitbart AS. Repair of palatal bone defects using osteogenically differentiated fat-derived stem cells. Plast Reconstr Surg. 2006 Mar;117(3):857-63.

41. Alhadlaq A, Elisseeff JH, Hong L, Williams CG, Caplan Al, Sharma B, Kopher RA, Tomkoria S, Lennon DP, Lopez A, Mao JJ. Adult Stem Cell Driven Genesis of Human-Shaped Articular Condyle. Ann Biomed Eng. 2004; 32(7):911-923.

42. Sharpe PT, Young CS. Test-Tube Teeth. Sci Am. 2005 Aug;293(2):34-41.

43. Young CS, Terada S, Vacanti JP, Honda M, Bartlett JD, Yelick PC. Tissue Engineering of Complex Tooth Structures on Biodegradable Polymer Scaffolds. J Dent Res. 2002; 81(10):695-700.

44. Ohazama A, Modino SAC, Miletich I, Sharpe PT. Stem-cell-based Tissue Engineering of Murine Teeth. J Dent Res. 2004; 83(7):518-522. 


\section{About the Authors}

\section{Fernanda Nedel}

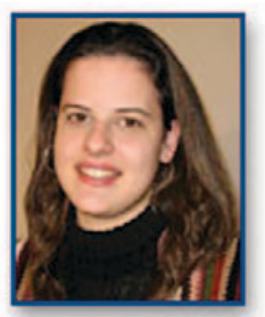

Miss Nedel is an undergraduate dental student in the School of Dentistry, Federal University of Pelotas, Pelotas, RS, Brazil. Her areas of interest include stem cells and molecular biology.

e-mail: fernandanedel@ hotmail.com

\section{Dárvi de Almeida André, DDS}

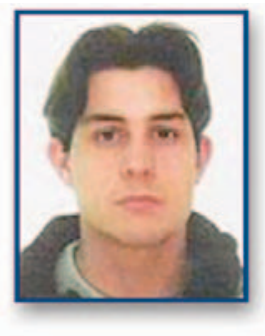

Dr. André is in private practice in São Lourenço, RS, Brazil.

e-mail: darviandre@yahoo.com.br

Isabel Oliveira de Oliveira, MSc, PhD

Dr. Oliveira is an Associate Professor in the Department of Phisiology and Pharmacology, Institute of Biology, Federal University of Pelotas, Pelotas, RS, Brazil. Her fields of interest include stem cells and molecular biology.

e-mail: olivisa@terra.com.br

Mabel M. Cordeiro, DDS, MS, PhD

Dr. Cordeiro is an Instructor in Pediatric Dentistry in the School of Dentistry, Federal University of Santa Catarina, Florianópolis, SC, Brazil. Her fields of interest include stem cells and pulp biology.

e-mail: mabelmrcordeiro@ hotmail.com

Luciano Casagrande, DDS, MS, PhD

Dr. Casagrande is an Associate Professor at the School of Dentistry, Centro Universitário Franciscano (UNIFRA), Santa Maria, RS, Brazil. His fields of interest are stem cells and pulp biology.

e-mail: lucianocasagrande@ hotmail.com

\section{Sandra Beatriz Chaves Tarquinio, DDS, MS, PhD}

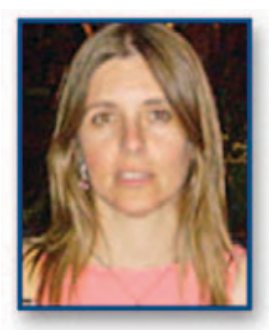

Dr. Tarquinio, is an Associate Professor in the Department of Oral Pathology, School of Dentistry, Federal University of Pelotas, Pelotas, RS, Brazil. Her fields of interest include stem cells and angiogenesis in oral cancer.

e-mail: sbtarquinio@gmail.com 
Jacques Eduardo Nor, DDS, MS, PhD

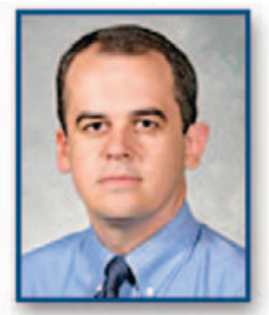

Dr. Nor is a Professor in the Department of Cariology, Restorative Sciences, and Endodontics, of the University of Michigan School of Dentistry and the Department of Biomedical Engineering, University of Michigan College of Engineering in Ann Arbor, MI, USA. His fields of interest are angiogenesis in cancer and tissue engineering.

e-mail: jenor@umich.edu

Flávio Fernando Demarco, DDS, PhD

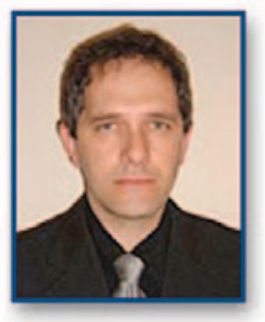

Dr. Demarco is an Associate Professor in the Department of Operative Dentistry, School of Dentistry, Federal University of Pelotas, Pelotas, RS, Brazil. His fields of interest include tissue engineering and oral epidemiology.

e-mail: flavio.demarco@pq.cnpq.br 